\title{
ANALISIS FAKTOR INTERNAL DAN EKSTERNAL BANK YANG MEMPENGARUHI PROFITABILITAS BANK UMUM DI INDONESIA
}

\author{
Aris Fadjar \\ S1 Manajemen \\ Institut Perbanas \\ Hedwigis Esti R. \\ Institut Perbanas \\ Tri Prihatini EKP. \\ Institut Perbanas
}

\begin{abstract}
The purpose of this research is to analyze the influence of internal factors of banks consisting of Capital Adequacy Ratio (CAR), Non-Performing Loans (NPLs), Operating Expenses Operating Income (BOPO), Loan to Deposit Ratio (LDR), and external factors of banks consisting of the value exchange rate of rupiah against the U.S. dollar, interest rate (SBI 1 month), and the inflation rate to Return On Asset (ROA) of the general bank. It used the secondary data from Indonesia Economic and Financial Statistic (SEKI) which published by Bank Indonesia monthly. The samples took from ROA of general bank as series, CAR, NPLs, BOPO, LDR, inflation rate, exchange rate rupiah to US \$, and SBI rate with period 2007-2010. The result shows, external factors of banks and CAR do not significantly influence to the ROA of general Bank, while internal factors are significantly influence to ROA general bank. As the simultaneous, the seven variables have positive significant influence to the ROA general bank it can be proofed with $F$ value $>F$ table (7.574 > 2.589). And all of the independence variables have had influenced for 52.9 percent to the ROA general bank.
\end{abstract}

Keywords:

$C A R$, NPLs, BOPO, LDR, exchange rates, interest rates, inflation rate and ROA 


\section{PENDAHULUAN}

Mediasi sektor keuangan tentu juga terkait dengan efisiensi pada perekonomian. Dengan demikian maka semakin baik tingkat mediasi suatu perbankan dalam pengumpulan serta penyaluran dananya maka perekonomian suatu negara tentu akan berkembang lebih cepat. Menurut Kunt dan Huizinga (1998) sektor keuangan juga sangat peka dan terpengaruh erat dengan kebijakan pemerintah serta kondisi ekonomi makro maupun mikro pada negara yang bersangkutan. Secara teoritis ada berbagai faktor yang dapat mempengaruhi kinerja dari sebuah bank baik faktor dari dalam (internal) bank itu sendiri. Faktor-faktor dari dalam (internal) tersebut antara lain kegiatan operasional bank, manajemen resiko, dan lain-lain. Sedangkan factor dari luar bank menurut Arsani (2008:3) meliputi kebijakan moneter, fluktuasi nilai tukar dan inflasi, volatilitas tingkat bunga, persaingan antar bank maupun lembaga keuangan non bank dan lain-lain".

Sebagai lembaga yang penting dalam perekonomian maka perlu adanya pengawasan kinerja yang baik oleh regulator perbankan. Salah satu indikator untuk menilai kinerja keuangan suatu bank adalah melihat tingkat profitabilitasnya. Hal ini terkait sejauh mana bank menjalankan usahanya secara efisien. Efisiensi diukur dengan membandingkan laba yang diperoleh dengan aktiva atau modal yang menghasilkan laba. Semakin tinggi profitabilitas suatu bank, maka semakin baik pula kinerja bank tersebut.

Faktor yang berpengaruh terhadap profitabilitas bank adalah karakteristik bank. Artinya bagaimana bank menjalankan operasinya serta jenis bank akan berdampak pada profitabilitasnya. Perbedaan pangsa pasar serta kegiatan operasi berkaitan erat dengan antisipasi terhadap kondisi makro seperti inflasi. Bila melihat dari pernyataan Kunt (1998 dalam jurnal Bank Specific, Industry Specific and Macroeconomic Determinants of Bank Profitability) tersebut maka makro ekonomi serta risiko bisnis berpengaruh berbeda antar jenis bank dan size bank tersebut.

Profitabilitas merupakan tingkat kemampuan bank dalam meningkatkan labanya. Tingkat profitabilitas dapat diukur menggunakan rasio return on asset (ROA), yang merupakan rasio untuk mengukur kemampuan manajemen dalam mengelola aktiva untuk menghasilkan laba. Rasio ini merupakan salah satu unsur dalam mengukur tingkat kesehatan bank (CAMEL) Bank Indonesia. Dalam kegiatan usaha bank yang mendorong perekonomian, rasio ROA yang tinggi menunjukkan bank telah menyalurkan kredit dan memperoleh pendapatan.

Identifikasi variabel makro yang dapat mempengaruhi profitabilitas perbankan perlu diketahui untuk mendapatkan kinerja yang maksimal. ROA penting bagi bank karena ROA digunakan untuk mengukur efektifitas perusahaan dalam menghasilkan keuntungan dengan memanfaatkan aktiva yang dimilikinya. ROA merupakan rasio antara laba sesudah pajak terhadap total asset. Menurut Husnan (1998:102) semakin besar ROA menunjukkan kinerja perusahaan semakin baik, kerena tingkat pengembalian (return) semakin besar.

Kondisi ekonomi yang semakin terkendali akan meningkatkan kepercayaan masyarakat dan investor terhadap perbankan sehingga pada akhirnya memacu pertumbuhan ekonomi secara keseluruhan. Oleh karena itu, pemantauan berkelanjutan terhadap indikator-indikator makro dapat memberikan informasi awal adanya permasalahan pada perbankan sehingga dapat secara tepat mengantisipasi dampak negatif dan manfaatkan dampak positif yang 
muncul guna menunjang kinerja perbankan secara keseluruhan.

Bedasarkan latar belakang tersebut di atas, penelitian ini bertujuan untuk menganalisis pengaruh faktor internal dan faktor eksternal bank terhadap profitabilitas Bank Umum.

\section{TINJAUAN LITERATUR}

\subsection{Faktor-faktor Internal Bank yang Mempengaruhi Profitabilitas Bank}

Menurut Riyadi (2006:169) cara penilaian Tingkat Kesehatan Bank (TKB) terjadi penyempurnaan dari waktu ke waktu, hal ini disebabkan karena Bank Indonesia sebagai Bank Sentral yang mempunyai tugas diantaranya mengatur dan mengawasi bank agar aktivitas perbankan di Indonesia dapat berjalan secara sehat. Tingkat kesehatan bank dinilai dengan pendekatan kuantitatif dan kualitatif atas berbagai aspek yang berpengaruh terhadap kondisi dan perkembangan suatu bank, yang meliputi faktor-faktor permodalan, kualitas aktiva produktif, manajemen, rentabilitas, dan likuiditas.

\subsubsection{Capital Adequacy Ratio (CAR)} Capital Adequacy Ratio (CAR) merupakan rasio permodalan yang menunjukkan kemampuan bank dalam menyediakan dana untuk keperluan pengembangan usaha serta menampung kemungkinan risiko kerugian yang diakibatkan dalam opersional bank. Menurut Achmad dan Kusumo (2003:146) semakin besar CAR suatu bank akan semakin baik posisi modal bank tersebut. Dalam Peraturan Bank Indonesia Nomor 10/15/PBI/2008 pasal 2 ayat 1 , bank wajib menyediakan modal minimum sebesar 8 persen dari asset tertimbang menurut risiko (ATMR). CAR adalah rasio yang memperlihatkan seberapa besar jumlah seluruh aktiva bank yang mengandung risiko (kredit, penyertaan, surat berharga, tagihan pada bank lain) ikut dibiayai dari modal sendiri disamping memperoleh dana-dana dari sumber-sumber di luar bank.

Pengertian CAR menurut Almilia (2005:73), Capital Adequacy Ratio adalah kecukupan modal yang menunjukkan kemampuan bank dalam mempertahankan modal yang mencukupi dan kemampuan manajeman bank dalam mengidentifikasi, mengukur, mengawasi, dan mengkontrol risiko-risiko yang timbul yang dapat berpengaruh terhadap besarnya modal. Perhitungan CAR didasarkan pada prinsip bahwa setiap penanaman yang mengandung risiko harus disediakan jumlah modal sebesar persentase tertentu terhadap jumlah penanamannya. Sejalan dengan standar yang ditetapkan Bank of International Settlements (BIS), seluruh bank yang ada di Indonesia diwajibkan untuk menyediakan modal minimum sebesar 8 persen dari ATMR (Kuncoro dan Suhardjono, 2002).

\subsubsection{Non Performing Loan (NPL)}

Tingkat kelangsungan usaha bank berkaitan erat dengan aktiva produktif yang dimilikinya, oleh karena itu manajemen bank dituntut untuk senantiasa dapat memantau dan menganalisis kualitas aktiva produktif yang dimiliki. Menurut Siamat (2005:350) kualitas aktiva produktif menunjukkan kualitas asset sehubungan dengan risiko kredit yang dihadapi oleh bank akibat pemberian kredit dan investasi dana bank. Aktiva produktif yang dinilai kualitasnya meliputi penanaman dana baik dalam rupiah maupun valuta asing, dalam bentuk kredit dan surat berharga. Setiap penanaman dana bank dalam aktiva produktif dinilai kualitasnya dengan menentukan tingkat kolektibilitasnya. Kolektibilitas dapat diartikan sebagai keadaan pembayaran 
kembali pokok hutang, angsuran pokok atau bunga kredit oleh nasabah serta tingkat kemungkinan diterima kembali dana yang ditanamkan dalam surat berharga atau penanaman lainnya. Risiko kredit yang diterima bank merupakan salah satu risiko usaha bank, yang diakibatkan dari tidak dilunasinya kembali kredit yang diberikan oleh pihak bank kepada debitur.

Menurut Hasibuan (2007:213) rasio kredit yang diterima oleh bank merupakan salah satu risiko usaha bank, yang diakibatkan dari ketidakpastian dalam pengembaliannya atau yang diakibatkan dari tidak dilunasinya kembali kredit yang diberikan oleh pihak bank kepada debitur. Sedangkan menurut surat edaran BI No. 3/30 DPNP tanggal 14 Desember 2001, NPL diukur dari rasio perbandingan antara kredit bermasalah terhadap total kredit yang diberikan. NPL yang tinggi akan memperbesar biaya, sehingga berpotensi terhadap kerugian bank. Semakin tinggi rasio ini maka akan semakin buruk kualitas kredit bank yang menyebabkan jumlah kredit bermasalah semakin besar, dan oleh karena itu bank harus menanggung kerugian dalam kegiatan operasionalnya sehingga berpengaruh terhadap penurunan laba (ROA) yang diperoleh bank (Kasmir,2004:74).

Kredit dalam hal ini adalah kredit yang diberikan kepada pihak ketiga tidak termasuk kredit kepada bank lain. Kredit bermasalah atau kredit dengan kualitas kurang lancar, diragukan, dan macet. Sesuai dengan aturan yang telah ditetapkan oleh Bank Indonesia, besarnya NPL yang baik adalah di bawah 5 persen. NPL merupakan tingkat risiko yang dihadapi bank. NPL adalah jumlah kredit yang bermasalah dan kemungkinan tidak dapat ditagih. Semakin besar nilai NPL maka semakin buruk kinerja bank tersebut (Muhamad,2005:106).

\subsubsection{Biaya Operasional Pendapatan Operasional (BOPO)}

Menurut Kuncoro dan Suhardjono (2002:61) keberhasilan bank didasarkan pada penilaian kuantitatif terhadap rentabilitas bank dapat diukur dengan menggunakan rasio biaya operasional terhadap pendapatan operasional. Menurut Dendawijaya (2005:315) rasio biaya operasional digunakan untuk mengukur tingkat efisiensi dan kemampuan bank dalam melakukan kegiatan operasionalnya. Rasio Biaya Operasional terhadap Pendapatan Operasional (BOPO) sering disebut rasio efisiensi digunakan untuk mengukur kemampuan manajemen bank dalam mengendalikan biaya operasional terhadap pendapatan operasional. Semakin kecil rasio ini berarti semakin efisien biaya operasional yang dikeluarkan bank yang bersangkutan (Almilia dan Herdaningtyas,2005:213).

\subsubsection{Loan to Deposit Ratio (LDR)}

Menurut Almilia dan Herdaningtyas (2005:215), LDR digunakan untuk menilai likuiditas suatu bank dengan cara membagi jumlah kredit dengan jumlah dana. Loan to Deposit Ratio (LDR) merupakan rasio yang menunjukkan kemampuan suatu bank dalam menyediakan dana kepada debiturnya dengan modal yang dapat dikumpulkan dari masyarakat. LDR merupakan rasio yang mengukur kemampuan bank untuk memenuhi kewajiban keuangan yang harus segera dipenuhi. Kewajiban tersebut berupa call money yang harus dipenuhi pada saat adanya kewajiban kliring, dimana pemenuhannya dilakukan dari aktiva lancar yang dimiliki perusahaan (Sudarini,2005:93). Menurut Achmad dan Kusumo (2003:54) Loan to Deposit Ratio menunjukkan kemampuan bank didalam menyediakan dana kepada debiturnya dengan modal yang dimiliki oleh bank maupun dana yang dikumpulkan dari 
masyarakat. Sedangkan menurut Dendiwijaya (2005:71) LDR menyatakan seberapa jauh kemampuan bank dalam membayar kembali penarikan dana yang dilakukan deposan dengan mengandalkan kredit yang diberikan sebagai sumber likuiditasnya.

Bank sangat diuntungkan apabila dapat menyalurkan seluruh dana yang dihimpun, namun hal ini terkait risiko apabila sewaktu-waktu pemilik dana menarik dananya atau pemakai dana tidak dapat mengembalikan dana yang dipinjamnya. Rasio ini menyatakan seberapa jauh kemampuan bank dalam membayar kembali penarikan dana yang dilakukan deposan dengan mengandalkan kredit atau pembiayaan yang diberikan sebagai likuiditasnya. Semakin tinggi rasio tersebut memberikan indikasi semakin rendahnya kemampuan likuiditas bank yang bersangkutan. Hal ini disebabkan karena jumlah dana yang diperlukan untuk pembiayaan menjadi semakin besar. Para praktisi perbankan menyepakati bahwa batas aman dari LDR adalah sekitar 80 persen. Namun batas toleransi berkisar antara 85-100 persen. Namun oleh Bank Indonesia, suatu bank masih dianggap sehat jika LDR nya masih di bawah 110 persen.

\subsection{Faktor-faktor Eksternal Bank yang Mempengaruhi Profitabilitas Perbankan}

Menurut Arsani (2008:20) faktorfaktor eksternal yang dapat mempengaruhi kinerja perbankan atau faktor yang berada diluar kendali bank misalnya situasi perekonomian yang terjadi dalam suatu negara. Situasi perekonomian tersebut diantaranya nilai tukar, tingkat suku bunga dan inflasi.

Nilai tukar terkait dengan mata uang negara lain (foreign currency) dari suatu perekonomian. Rasio pertukaran (harga) yang menggambarkan berapa banyak suatu mata uang harus dipertukarkan untuk memperoleh satu unit mata uang lain disebut dengan nilai tukar (exchange rate). Menguatnya nilai tukar karena mekanisme pasar disebut apresiasi sedangkan melemahnya nilai tukar mata uang karena kekuatan pasar disebut depresiasi. Nilai tukar akan memberikan resiko kepada bank terutama yang melakukan transaksi yang terkait dengan mata uang asing baik dari sisi aktiva maupun dari sisi pasiva. Ketidakstabilan nilai tukar akan menyebabkan bank mengalami kesulitan dalam mengelola aktiva dan kewajiban yang dimilikinya dalam mempertahankan keuntungan sesuai target.

Menurut Mankiw (2003:192) kurs (exchange rate) di antara dua negara adalah harga dimana penduduk kedua negara saling melakukan perdagangan. Sedangkan menurut Sukirno (2008:397) kurs valuta asing atau kurs mata uang asing menunjukkan harga atau nilai mata uang sesuatu negara dinyatakan dalam nilai mata uang negara lain. Kurs valuta asing dapat juga didefinisikan sebagai jumlah uang domestik yang dibutuhkan, yaitu banyaknya rupiah yang dibutuhkan, untuk memperoleh satu unit mata uang asing (dalam hal ini, dolar Amerika).

Pengertian suku bunga menurut Arsani (2008:21) suku bunga yang dimaksud adalah tingkat bunga yang berlaku dalam suatu negara yang berfluktuasi dari tingkat yang satu ketingkat yang lainnya, dalam hal ini yang dimaksud adalah suku bunga SB dan semenjak Bulan September 2005 Bank Indonesia menggunakan $B I$ rate sebagai acuan suku bunga yang berlaku di Indonesia.

$$
\text { Menurut Fahmi (1997:74) }
$$
pergerakan dalam suku bunga SBI menjadi tolok ukur bagi tingkat suku bunga lainnya, sehingga kenaikan dalam suku bunga SBI diikuti pula oleh kenaikan dalam tingkat 
suku bunga dana antar bank dan suku bunga deposito. Jika suku bunga pasar uang meningkat maka otomatis tingkat pendapatan nasional menjadi tinggi. Dengan tingginya tingkat suku bunga, masyarakat akan mengalirkan dananya keperbankan namun disisi lain aktivitas untuk menyalurkan dana perbankan dalam bentuk kredit menjadi terhalang karena suku bunga pinjaman biasanya jauh lebih tinggi dari suku bunga simpanan, akibatnya investor sulit melakukan kegiatan ekspansi usahanya. Di Indonesia, SBI adalah sekuritas dalam rangka melaksanakan kebijakan moneter melalui operasi pasar terbuka (open market operation). Bila jumlah uang beredar ingin dikurangi, Bank Indonesia menjual SBI. Agar minat membeli SBI semakin tinggi, Bank Indonesia dapat menaikkan tingkat suku bunga SBI atau sebaliknya. Mengingat risiko SBI sangat kecil (paling kecil), biasanya tingkat suku bunga SBI paling rendah diantara instrumen pasar uang lainnya.

Tingkat Inflasi, menurut Arsani (2008:23) adalah suatu peristiwa moneter yang menunjukkan suatu kecendrungan naiknya harga barang-barang secara umum dan terus-menerus serta mengakibatkan terjadinya penurunan nilai uang. Inflasi dapat disebabkan karena dorongan tekanan permintaan ataupun akibat kenaikan biaya produksi. Teori Kuantitas mengenai uang bahwa kelebihan uang beredar akibat penambahan jumlah uang di masyarakat akan menimbulkan inflasi. Pada saat terjadi inflasi, Bank Indonesia akan menarik uang yang beredar, sebaliknya jika terjadi kelesuhan usaha, akan dilakukan penyaluran usaha untuk menunjang kegiatan usaha masyarakat. Untuk menghadapi inflasi, perbankan nasional biasanya akan berusaha mengimbangi dengan meminta tingkat bunga yang lebih tinggi.

\subsection{Kajian Penelitian Terdahulu}

Beberapa penelitian telah dilakukan untuk melihat hubungan antara indikator makroekonomi dan profitabilitas perbankan. Revell (1979) dalam Athanasoglou (2005:9) mengenalkan hubungan antara inflasi dengan profitabilitas perbankan dimana ia berpendapat bahwa pengaruh dari inflasi tersebut tergantung pada tingkat pengeluaran bank yang bergerak lebih cepat atau lebih lambat daripada inflasi. Hal ini juga terkait dengan peramalan suatu ekonomi terhadap inflasi di masa depan. Masih dalam penelitian yang serupa Perry (1992) dalam Athanasoglou (2005:20) berpendapat bahwa pengaruh dari inflasi tergantung pada antisipasi terhadap ekspektasi inflasi itu sendiri.

Menurut Kunt dan Huizinga (2000) dalam Athanasoglou (2005:10) hasil penelitiannya menunjukkan bahwa suku bunga dan produk domestik bruto terkait dengan profitabilitas perbankan. Hal ini menunjukkan bahwa indikator makroekonomi memiliki pengaruh terhadap profitabilitas perbankan.

Kunt dan Demirgue (1998) dalam Arsani (2008:24) menunjukkan bahwa pemulihan perbankan terjadi pada kondisi perekonomian yang memburuk. Oleh karena itu, penelitiannya mencoba menganalisa pengaruh dari indikator makroekonomi terhadap profitabilitas perbankan di Indonesia. Fokus utama penelitian tersebut mencakup pada pengaruh nilai tukar, inflasi, indeks produksi, suku bunga, jumlah uang beredar, dan harga minyak dunia terhadap profitabilitas perbankan.

Nilai tukar akan mempengaruhi perbankan karena bank memperoleh pendanaan dan menyalurkannya kembali baik dalam bentuk rupiah ataupun mata uang asing sehingga pendapatan yang diterima juga tergantung pada fluktuasi nilai tukar yang sedang terjadi. Oleh karena itu, risiko 
nilai tukar berpengaruh penting terhadap profit yang dihasilkan oleh bank. Depresiasi rupiah akan menyebabkan kewajiban usaha bank akan bertambah yang akan mengurangi profit bank sehingga biasanya terdapat pengaruh yang negatif dari nilai tukar terhadap profit bank. Pazarbasioglu (1998) dalam Arsani (2008:24) juga berpendapat bahwa apresiasi nilai tukar yang disertai depresiasi yang tajam merupakan salah satu faktor tertentu yang menimbulkan permasalahan pada perbankan di Asia.

Menurut Beryd (2006) dalam Arsani (2008:25) menyatakan bahwa inflasi akan memberikan pengaruh negatif terhadap profitabilitas perbankan. Penelitian yang dilakukannya menunjukkan bahwa NIM, net profit, rate of $R O E$, dan value added dari sektor perbankan mengalami penurunan ketika inflasi meningkat. Hal ini dikarenakan ketika terjadi inflasi tingkat lending berkurang sehingga pendapatannya juga berkurang.

Limpaphayom dan Polwitoon (2004) meneliti tentang pengaruh CAR terhadap ROA menunjukkan adanya pengaruh yang negatif antara CAR dan ROA. Hasil penelitian tersebut berbeda dengan hasil penelitian yang dilakukan Suyono (2005) yang menunjukkan adanya pengaruh yang signifikan positif antara CAR dengan ROA.

Loan to Deposit Ratio (LDR) juga merupakan indikator penting dari kinerja suatu perbankan yang pada dasarnya menunjukkan seberapa jauh pembiayaan produktif yang disalurkan oleh bank untuk mendapatkan profit dibandingkan dengan total dana pihak ketiganya. Hasil penelitian mengenai LDR yang diteliti oleh Limpaphayom dan Polwitoon (2004) menunjukkan adanya pengaruh negatif antara LDR terhadap ROA. Hasil penelitian Limpaphayom dan Polwitoon (2004) berbeda dengan hasil penelitian Suyono (2005) yang menunjukkan adanya pengaruh yang signifikan positif antara LDR dengan ROA.

NPL merupakan rasio yang menunjukkan tingkat kolektabilitas dari dana yang telah disalurkan. Semakin tinggi tingkat Non Performing Loan (NPL) maka kinerja bank semakin buruk dan profitabilitasnya rendah. Non Performing Loan (NPL) yang diteliti Limpaphayom dan Polwitoon (2004), menunjukkan bahwa NPL, berpengaruh positif terhadap ROA.

BOPO merupakan rasio yang menunjukkan kemampuan bank dalam menjalankan operasionalnya secara esfisien. Teori yang ada menjelaskan bahwa hubungan antara BOPO dan ROA adalah berbanding terbalik. Angka standar untuk rasio BOPO adalah di bawah 90 persen (PBI), jika rasio BOPO yang dihasilkan suatu bank lebih dari 90 persen, maka dapat disimpulkan bahwa bank tersebut tidak efisien dalam menjalankan operasinya. Jika rasio BOPO berada kondisi efisiensi, laba yang akan diperoleh semakin besar karena biaya operasi yang ditanggung bank semakin kecil. Dengan meningkatnya laba maka dapat dipastikan bahwa ROA dapat meningkat.

Penelitian yang dilakukan Mawardi (2005), menyimpulkan bahwa BOPO berpengaruh negatif terhadap profitabilitas bank yang diproksikan dengan ROA. Hal ini menunjukkan bahwa semakin besar perbandingan total biaya operasional dengan pendapatan operasional akan berakibat turunnya ROA. Demikian juga Usman (2003) dalam penelitiannya menunjukkan bahwa BOPO berpengaruh signifikan terhadap laba bank sehingga diprediksi BOPO juga mempunyai pengaruh yang signifikan terhadap ROA karena ROA dipengaruhi oleh laba. Dengan mengetahui pengaruh yang mungkin ditimbulkan dari indikator internal bank dan indikator makroekonomi terhadap profitabilitas 
perbankan seperti yang telah disebutkan di atas akan membantu perbankan untuk bekerja secara maksimal sehingga dapat menyokong perekonomian nasional secara berkelanjutan.

\section{METODOLOGI}

Populasi dalam penelitian ini adalah Return On Asset (ROA) bank umum yang dipublikasikan oleh Bank Indonesia. Laporan Capital Adequacy Ratio (CAR), laporan Non Performing Loan (NPL), laporan Biaya Operasional Pendapatan Operasional (BOPO), laporan Loan to Deposit Ratio (LDR), laporan Return On Equity (ROE), Cost Efficiency Ratio (CER), Net Interest Margin (NIM), Government Bond Trading Ratio (GBTR), laporan nilai tukar rupiah terhadap dolar Amerika, laporan data suku bunga (SBI $1 \mathrm{bln}$ ), data jumlah uang beredar (M1) serta laporan tingkat inflasi yang dipublikasikan oleh Bank Indonesia. Sampel yang digunakan adalah sampel jenuh karena sampel yang digunakan sudah ditentukan terlebih dahulu yang terdiri dari data Return On Asset (ROA) bank umum, Capital Adequacy Ratio (CAR), Non Performing Loan (NPL), Biaya Operasional Pendapatan Operasional (BOPO), Loan to Deposit Ratio (LDR), nilai tukar rupiah terhadap dolar Amerika, suku bunga (SBI 1 bln), tingkat inflasi periode Januari 2007-Juni 2010.

Teknik pengumpulan data yang digunakan dalam penelitian ini adalah teknik non probability sampling dimana peneliti mengambil sampel dengan tidak memberi peluang atau kesempatan yang sama bagi setiap unsur atau anggota populasi untuk dipilih karena mempertimbangkan hal tertentu.

Variabel operasional yang digunakan dalam penelitian ini, dapat dilihat pada tabel 1.

Tabel 1.

Variabel Operasional

\begin{tabular}{|c|c|c|c|c|}
\hline Variabel & Konsep Variabel & Indikator & Rumus & Rasio \\
\hline Profitabilitas & $\begin{array}{l}\text { Kemampuan perusahaan } \\
\text { dalam meningkatkan } \\
\text { pendapatan, atau dalam } \\
\text { mendapatkan laba yang } \\
\text { dinyatakan secara tertulis } \\
\text { dalam SPI (Statistik } \\
\text { Perbankan Indonesia) } \\
\text { dalam data perkembangan } \\
\text { dan sebagai data perbulan. }\end{array}$ & $\begin{array}{l}\text { Laba Sebelum Pajak } \\
\text { Total Asset (Rata- } \\
\text { rata) }\end{array}$ & $\frac{\text { Laba sebelum pajak }}{\text { Total Asset (rata-rata) }} \times 100 \%$ & Rasio \\
\hline CAR & $\begin{array}{lr}\text { Rasio } & \text { kewajiban } \\
\text { pemenuhan } & \text { modal } \\
\text { minimum yang } & \text { harus } \\
\text { dimiliki oleh bank. } & \\
\end{array}$ & $\begin{array}{l}\text { Modal } \\
\text { ATMR }\end{array}$ & $\frac{\text { Modal }}{\text { ATMR }}$ X 100\% & Rasio \\
\hline NPL & 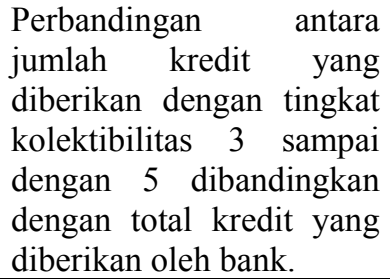 & $\begin{array}{l}\text { Kredit yang diberikan } \\
\text { dengan kolektibilitas } \\
3 \mathrm{~s} / \mathrm{d} 5 \\
\text { Total Kredit yang } \\
\text { diberikan }\end{array}$ & $\begin{array}{l}\text { Kredit yang diberikan dengan } \\
\text { kolektibilitas } 3 \mathrm{~s} / \mathrm{d} 5 \\
\text { Total Kredit yang diberikan }\end{array}$ & Rasio \\
\hline
\end{tabular}




\begin{tabular}{|c|c|c|c|c|}
\hline BOPO & $\begin{array}{lr}\text { Rasio } & \text { perbandingan } \\
\text { antara biaya } & \text { operasional } \\
\text { dengan } & \text { pendapatan } \\
\text { operasional. } & \\
\end{array}$ & $\begin{array}{l}\text { Biaya Operasi } \\
\text { Pendapatan Operasi }\end{array}$ & $\frac{\text { Biaya Operasi }}{\text { Pendapatan Operasi }} \times 100 \%$ & Rasio \\
\hline$\overline{L D R}$ & $\begin{array}{l}\text { Perbandingan antara total } \\
\text { kredit yang diberikan } \\
\text { dengan total Dana Pihak } \\
\text { Ketiga (DPK) yang dapat } \\
\text { dihimpun oleh bank. }\end{array}$ & $\begin{array}{l}\text { Total Kredit yang } \\
\text { diberikan } \\
\text { Total DPK }\end{array}$ & $\frac{\text { Tot.Kredit yang diberikan }}{\text { Tot.DPK }} \quad$ X 100\% & Rasio \\
\hline $\begin{array}{l}\text { Nilai Tukar } \\
\text { Rupiah } \\
\text { terhadap } \\
\text { Dolar } \\
\text { Amerika }\end{array}$ & $\begin{array}{lr}\text { Rasio pertukaran (harga) } \\
\text { yang menggambarkan } \\
\text { berapa banyak suatu mata } \\
\text { uang (IDR) harus } \\
\text { dipertukarkan untuk } \\
\text { memperoleh satu unit } \\
\text { mata uang (USD). } & \\
\end{array}$ & $\begin{array}{l}\text { Kurs tengah dollar } \\
\text { Amerika terhadap } \\
\text { Rupiah di Indonesia }\end{array}$ & $\begin{array}{lr}\text { Dalam laporan SEKI (Statistik } \\
\text { Ekonomi } \\
\text { Indonesia) }\end{array}$ & Rasio \\
\hline $\begin{array}{l}\text { Suku Bunga } \\
\text { (SBI } 1 \text { bln) }\end{array}$ & \begin{tabular}{lrr} 
Bunga & sekuritas & dalam \\
rangka & melaksanakan \\
kebijakan & \multicolumn{2}{r}{ moneter } \\
melalui operasi pasar \\
terbuka (open market \\
operation).
\end{tabular} & $\begin{array}{l}\text { Suku bunga SBI } 1 \\
\text { bln per Annum }\end{array}$ & $\begin{array}{l}\text { Suku bunga SBI } 1 \text { bln per } \\
\text { bulan }\end{array}$ & Rasio \\
\hline $\begin{array}{l}\text { Tingkat } \\
\text { Inflasi }\end{array}$ & $\begin{array}{l}\text { Meningkatnya harga } \\
\text { barang dan jasa yang } \\
\text { diukur dalam IHK (Indeks } \\
\text { Harga Konsumen) dalam } \\
\text { data BPS (Badan Pusat } \\
\text { Statistik). }\end{array}$ & $\begin{array}{l}\text { Tingkat harga }(\mathrm{t}) \\
\text { Tingkat harga }(\mathrm{t}-1)\end{array}$ & $\frac{(\mathrm{t})-(\mathrm{t}-1)}{(\mathrm{t}-1)}$ & Rasio \\
\hline
\end{tabular}

sumber : Peneliti (2011)

Perumusan hipotesis penelitian terdapat pada Tabel 2.

Tabel 2.

Perumusan Hipotesis

\begin{tabular}{|c||l||}
\hline $\mathrm{Ho}_{1}$ & $\begin{array}{l}\text { Tidak ada pengaruh antara Capital Adequacy Ratio (CAR) terhadap Return On Asset (ROA) } \\
\text { bank umum. }\end{array}$ \\
\hline \hline $\mathrm{Ha}_{1}$ & $\begin{array}{l}\text { Ada pengaruh antara Capital Adequacy Ratio (CAR) terhadap Return On Asset (ROA) bank } \\
\text { umum. }\end{array}$ \\
\hline \hline $\mathrm{Ho}_{2}$ & $\begin{array}{l}\text { Tidak ada pengaruh antara Non Performing Loan (NPL) terhadap Return On Asset (ROA) bank } \\
\text { umum. }\end{array}$ \\
\hline $\mathrm{Ha}_{2}$ & $\begin{array}{l}\text { Ada pengaruh antara Non Performing Loan (NPL) terhadap Return On Asset (ROA) bank } \\
\text { umum. }\end{array}$ \\
\hline $\mathrm{Ho}_{3}$ & $\begin{array}{l}\text { Tidak ada pengaruh antara Biaya Operasional Pendapatan Operasional (BOPO) terhadap } \\
\text { Return On Asset (ROA) bank umum. }\end{array}$ \\
\hline $\mathrm{Ha}_{3}$ & $\begin{array}{l}\text { Ada pengaruh antara Biaya Operasional Pendapatan Operasional (BOPO) terhadap Return On } \\
\text { Asset (ROA) bank umum. }\end{array}$ \\
\hline $\mathrm{Ho}_{4}$ & $\begin{array}{l}\text { Tidak ada pengaruh antara Loan to Deposit Ratio (LDR) terhadap Return On Asset (ROA) bank } \\
\text { umum. }\end{array}$ \\
\hline
\end{tabular}




\begin{tabular}{||c||l||}
\hline $\mathrm{Ha}_{4}$ & $\begin{array}{l}\text { Ada pengaruh antara Loan to Deposit Ratio (LDR) terhadap Return On Asset (ROA) bank } \\
\text { umum. }\end{array}$ \\
\hline \hline $\mathrm{Ho}_{5}$ & $\begin{array}{l}\text { Tidak ada pengaruh antara nilai tukar rupiah terhadap dolar Amerika terhadap Return On Asset } \\
\text { (ROA) bank umum. }\end{array}$ \\
\hline \hline $\mathrm{Ha}_{5}$ & $\begin{array}{l}\text { Ada pengaruh antara nilai tukar rupiah terhadap dolar Amerika terhadap Return On Asset } \\
\text { (ROA) bank umum. }\end{array}$ \\
\hline $\mathrm{Ho}_{6}$ & $\begin{array}{l}\text { Tidak ada pengaruh antara Suku Bunga (SBI 1 bln) terhadap Return On Asset (ROA) bank } \\
\text { umum. }\end{array}$ \\
\hline $\mathrm{Ha}_{6}$ & Ada pengaruh antara Suku Bunga (SBI 1 bln) terhadap Return On Asset (ROA) bank umum. \\
\hline \hline $\mathrm{Ho}_{7}$ & \begin{tabular}{l} 
Tidak ada pengaruh antara tingkat inflasi terhadap Return On Asset (ROA) bank umum. \\
\hline $\mathrm{Ha}_{7}$
\end{tabular} Ada pengaruh antara tingkat inflasi terhadap Return On Asset (ROA) bank umum. \\
\hline \hline $\mathrm{Ho}_{8}$ & $\begin{array}{l}\text { Tidak ada pengaruh antara internal bank dan indikator makroekonomi secara simultan terhadap } \\
\text { Return On Asset (ROA) bank umum. }\end{array}$ \\
\hline \hline $\mathrm{Ha}_{8}$ & $\begin{array}{l}\text { Ada pengaruh antara internal bank dan indikator makroekonomi secara simultan terhadap } \\
\text { Return On Asset (ROA) bank umum. }\end{array}$ \\
\hline
\end{tabular}

sumber : Peneliti (2011)

Untuk menguji pengaruh variabel

bebas terhadap variabel terikat dalam

penelitian ini digunakan persamaan regresi berganda sebagai berikut (Gambar 1.):

$$
Y=\alpha+\beta_{1} X_{1}+\beta_{2} X_{2}+\beta_{3} X_{3}+\beta_{4} X_{4}+\beta_{5} X_{5}+\beta_{6} X_{6}+\beta_{7} X_{7}
$$

Keterangan :

$\begin{array}{lll}\mathrm{Y} & = & \text { Return On Asset (ROA) bank umum } \\ \mathrm{X}_{1} & = & \text { Capital Adequacy Ratio (CAR) } \\ \mathrm{X}_{2} & = & \text { Non Performing Loan }(\mathrm{NPL}) \\ \mathrm{X}_{3} & = & \text { Biaya Operasional Pendapatan Operasional (BOPO) } \\ \mathrm{X}_{4} & = & \text { Loan to Deposit Ratio (LDR) } \\ \mathrm{X}_{5} & = & \text { Nilai tukar rupiah terhadap dolar Amerika } \\ \mathrm{X}_{6} & = & \text { Suku bunga (SBI } 1 \text { bln) } \\ \mathrm{X}_{7} & = & \text { Tingkat inflasi } \\ \alpha & = & \left.\text { Konstanta (nilai Y apabila } \mathrm{X}_{1}, \mathrm{X}_{2}, \mathrm{X}_{3}, \mathrm{X}_{4}, \mathrm{X}_{5}, \mathrm{X}_{6}, \mathrm{X}_{7}=0\right) \\ \beta & = & \text { Koefisien regresi (nilai peningkatan ataupun penurunan) }\end{array}$

sumber : Peneliti (2011) Gambar 1.

Persamaan Regresi Berganda

\section{ANALISIS DAN PEMBAHASAN}

\subsection{Uji T test dan Uji F test}

Analisis pengaruh secara parsial variabel independen (variabel Capital Adequacy Ratio (CAR), Non Performing Loan (NPL), Biaya Operasional Pendapatan Operasional (BOPO), Loan to Deposit Ratio (LDR), nilai tukar rupiah terhadap dolar Amerika, suku bunga SBI, tingkat inflasi) terhadap Return On Asset (ROA) bank umum dalam penelitian ini digunakan pengujian hipotesis uji t. Hasil uji $\mathrm{t}$ dapat dilihat pada Tabel 3. 
Tabel 3.

Hasil Uji t Coefficients ${ }^{\mathrm{a}}$

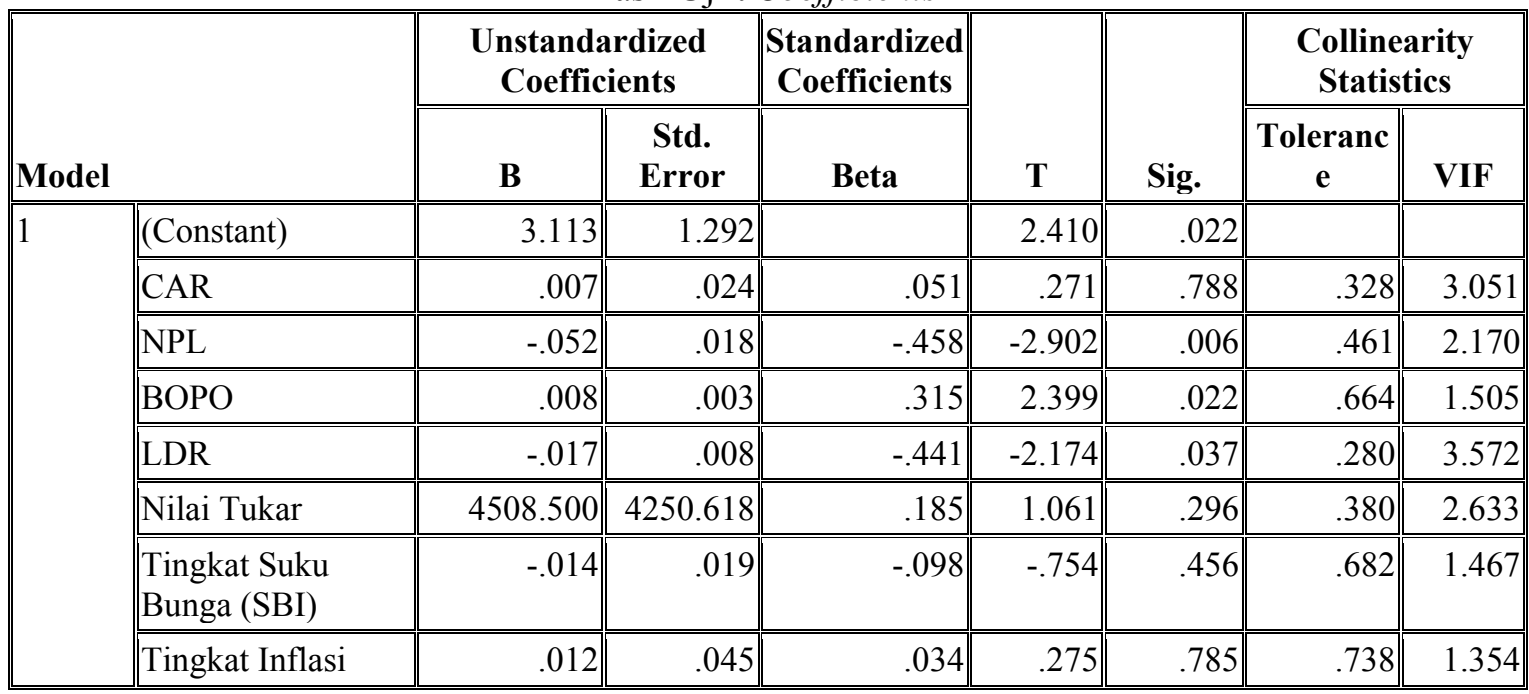

a. Dependent variable : ROA bank umum sumber : Data diolah (2011)

Secara parsial, terdapat 3 (tiga) variabel yaitu NPL, BOPO dan LDR berpengaruh signifikan terhadap ROA bank umum dan ada 4 (empat) variabel masingmasing CAR, nilai tukar, tingkat suku bunga (SBI), dan tingkat inflasi tidak berpengaruh signifikan terhadap ROA bank umum.
Analisis secara simultan variabel CAR, NPL, BOPO, LDR, nilai tukar, tingkat suku bunga, dan tingkat inflasi terhadap ROA bank umum, digunakan pengujian hipotesis uji F. Hasil uji hipotesis F terdapat pada Tabel 4.

Tabel 4.

Hasil Uji Hipotesis F

\begin{tabular}{|c|c|c|c|c|c|c|}
\hline \multicolumn{7}{|c|}{ ANOVA $^{b}$} \\
\hline \multicolumn{2}{|c|}{ Model } & Sum of Squares & Df & Mean Square & $\mathbf{F}$ & Sig. \\
\hline \multirow[t]{3}{*}{1} & Regression & 1.000 & 7 & .143 & 7.574 & $.000^{\mathrm{a}}$ \\
\hline & Residual & .641 & 34 & .019 & & \\
\hline & Total & 1.641 & 41 & & & \\
\hline \multicolumn{7}{|c|}{\begin{tabular}{|l} 
a. Predictors: (Constant), Tingkat Inflasi, LDR, Tingkat Suku Bunga (SBI), NPL, BOPO, Nilai \\
Tukar, CAR
\end{tabular}} \\
\hline \multicolumn{7}{|c|}{ b. Dependent Variable: ROA bank umum } \\
\hline
\end{tabular}

sumber : Data diolah (2011)

Berdasarkan uji hipotesis $\mathrm{F}$, yang lebih kecil dari taraf signifikan sebesar diperoleh nilai $F$ hitung sebesar 7,574 dengan nilai $F$ statistik signifikansi 0,000 0,05 . Hal ini menunjukkan bahwa secara simultan ada pengaruh yang signifikan antara 
variabel Capital Adequacy Ratio (CAR), Non Performing Loan (NPL), Biaya Operasional Pendapatan Operasional (BOPO), Loan to Deposit Ratio (LDR), nilai tukar rupiah terhadap dolar Amerika, suku bunga SBI, tingkat inflasi terhadap variabel Return On Asset (ROA) bank umum.

\subsection{Kontribusi Variabel Independent Terhadap Variabel Dependent \\ Untuk melihat besarnya kontribusi} variable bebas terhadap variable terikat dalam penelitian ini didasarkan pada nilai koefisien determinasi berganda $\left(\mathrm{R}^{2}\right)$ (Tabel 5.).

Tabel 5.

Hasil Uji Koefisien Determinasi Berganda

\begin{tabular}{|c||c||c||c||c|}
\hline \hline Model & R & R square & Adjusted R square & std. Error of the Estimate \\
\hline \hline 1 & $.781^{\mathrm{a}}$ & .609 & 529 & 13731 \\
\hline
\end{tabular}

Predictors: (Constant), Tingkat Inflasi, LDR, Tingkat Suku Bunga (SBI), NPL, BOPO, Nilai Tukar, CAR Dependent Variable: ROA bank umum sumber : Dara diolah (2011)

Besarnya koefisien Adjusted $R^{2}$ adalah 0,529 yang berarti bahwa variabel bebas yang terdiri dari Capital Adequacy Ratio (CAR), Non Performing Loan (NPL), Biaya Operasional Pendapatan Operasional (BOPO), Loan to Deposit Ratio (LDR), nilai tukar rupiah terhadap dolar Amerika, suku bunga SBI, tingkat inflasi mampu menjelaskan variasi dari variabel tidak bebas, yaitu Return On Asset (ROA) bank umum 52,9 persen dan sisanya 47,1 persen adalah variasi dari variabel bebas lain yang tidak dimasukkan ke dalam model persamaan.

\subsection{Perbandingan Hasil Penelitian dengan Penelitian Terdahulu \\ Rangkuman mengenai perbandingan} hasil penelitian ini dengan penelitian terdahulu yang serupa adalah sebagai berikut (Tabel 6.):

Tabel 6.

Ringkasan Hasil Penelitian

\begin{tabular}{|c|c|c|c|c|}
\hline No & Peneliti & Variabel Bebas & $\begin{array}{c}\text { Hubungan dengan } \\
\text { Variabel Terikat } \\
\end{array}$ & Signifikan \\
\hline 1 & $\begin{array}{l}\text { Limpaphayom } \\
\text { dan Polwitoon, } \\
2004\end{array}$ & $\begin{array}{l}\text { a. CAR } \\
\text { b. LDR } \\
\text { c. NPL } \\
\text { d. BOPO } \\
\end{array}$ & $\begin{array}{c}\text { Negative } \\
\text { negatif } \\
\text { positif } \\
\text { positif } \\
\end{array}$ & $\begin{array}{l}\text { Tidak Signifikan } \\
\text { Signifikan } \\
\text { Signifikan } \\
\text { Signifikan } \\
\end{array}$ \\
\hline 2 & Suyono, 2005 & $\begin{array}{l}\text { a. CAR } \\
\text { b. LDR } \\
\text { c. NPL }\end{array}$ & $\begin{array}{l}\text { Positif } \\
\text { Positif } \\
\text { negatif }\end{array}$ & $\begin{array}{l}\text { Signifikan } \\
\text { Signifikan } \\
\text { Tidak Signifikan }\end{array}$ \\
\hline 3 & $\begin{array}{l}\text { Athanasoglou, } \\
2005\end{array}$ & $\begin{array}{l}\text { a. Nilai Tukar } \\
\text { b. SBI } \\
\text { c. Inflasi }\end{array}$ & $\begin{array}{l}\text { Positif } \\
\text { negatif } \\
\text { Negatif }\end{array}$ & $\begin{array}{l}\text { Signifikan } \\
\text { Signifikan } \\
\text { Signifikan }\end{array}$ \\
\hline 4. & Arsani, 2009 & $\begin{array}{l}\text { a. Inflasi } \\
\text { b. Nilai Tukar } \\
\text { c. SBI }\end{array}$ & $\begin{array}{l}\text { Negative } \\
\text { Negative } \\
\text { Negative }\end{array}$ & $\begin{array}{l}\text { Signifikan } \\
\text { Signifikan } \\
\text { Signifikan }\end{array}$ \\
\hline
\end{tabular}




\begin{tabular}{|c||l||l||l||l||}
\hline 5. & Hedwigis, & a. CAR & Positif & Tidak Signifikan \\
& Prihatini, dan & b. NPL & Negatif & Signifikan \\
& Aris, 2011 & c. BOPO & Positif & Signifikan \\
& & d. LDR & Negatif & Signifikan \\
& & e. Nilai Tukar & Positif & Tidak Signifikan \\
& & f. SBI & Negatif & Tidak Signifikan \\
& & g. Inflasi & Positif & Tidak Signifikan \\
\hline
\end{tabular}

sumber : Peneliti (2011)

\section{KESIMPULAN DAN REKOMENDASI}

\subsection{Kesimpulan}

Hasil penelitian ini, secara parsial faktor eksternal bank yang terdiri Nilai Tukar, Tingkat Suku Bunga (SBI) dan Tingkat Inflasi tidak berpengaruh signifikan terhadap Return On Asset (ROA) Bank Umum, sedangkan faktor internal bank berpengaruh signifikan terhadap Return On Asset (ROA) Bank Umum kecuali CAR.

Faktor yang paling dominan mempengaruhi Return On Asset (ROA) bank umum dalam penelitian ini adalah Non Performing Loan (NPL). Hal ini terlihat pada hasil uji t dimana variabel NPL berpengaruh signifikan lebih kecil dari pada variabel lainnya.

Secara simultan faktor internal (CAR, NPL, BOPO, LDR) dan eksternal (nilai tukar rupiah terhadap dolar Amerika, tingkat suku bunga (SBI) dan tingkat inflasi) berpengaruh signifikan terhadap Return On asset (ROA) Bank Umum.

Kontribusi dari variabel (Capital Adequacy Ratio (CAR), Non Performing Loan (NPL), Biaya Operasional dan Pendapatan Operasional (BOPO), Loan to Deposit Ratio (LDR), nilai tukar rupiah terhadap dolar Amerika, tingkat suku bunga (SBI 1 bln) dan tingkat inflasi) sebesar 52,9 persen, sedangkan 47,1 persen dijelaskan oleh variabel lain.

\subsection{Rekomendasi}

Penelitian selanjutnya sebaiknya menambah faktor internal dan eksternal bank yang dapat mempengaruhi profitabilitas bank dalam berbagai jenis bank yang beroperasi di Indonesia. 


\section{DAFTAR PUSTAKA}

Achmad, Tarmizi dan Willyanto Kartiko Kusuno. 2003. "Analisis rasio-rasio keuangan sebagai predictor dalam memprediksi potensi kebangkrutan perbankan di Indonesia". Media Ekonomi dan Bisnis. Vol.XV, No.1.

Ahmad Zaki Fahmi. 1997. "Indikator ekonomi dan bisnis kuartal keempat 1997. Jurnal Bisnis dan Ekonomi Politik. Vol 1 (4): 73-88.

Agus Suyono. 2005. "Analisis rasio-rasio bank yang berpengaruh terhadap ROA". Tesis Program Pascasarjana. Universitas Diponegoro. Semarang.

Almilia dan Herdaningtyas. 2005. "Analisis rasio camel terhadap prediksi kondisi bermasalah pada lembaga perbankan 2000-2002”. Jurnal Akuntansi dan Keuangan,vol 7, No.2.

Badan Pusat Statistik, http://www.bps.go.id/aboutus.php?tabel=1\&id_subyek=03, diakses 2 Januari 2011.

Bank Indonesia. 2009. Booklet Perbankan Indonesia 2009.

-Laporan inflasi data indeks harga konsumen (IHK). http://www.bps.go.id/aboutus.php?inflasi=1, diakses 10 Januari 2011.

Statistik keuangan Indonesia (SEKI). http://www.bi.go.id/web/id/Statistik+Ekonomi+dan+Keuangan+Indonesia/Dokumentasi+Histori/, diakses 10 Januari 2011.

Bahtiar Usman. 2003. "Analisis ratio keuangan dalam memprediksi perubahan laba pada bank umum di Indonesia". Media Riset Bisnis dan Manajemen. Vol 3 No 1. April 2003, pp.59-74.

Boy Loen dan Sonny Ericson. 2005. Manajamen aktiva pasiva bank. Jakarta: STIEP Press.

Boediono. 1990. Ekonomi moneter. Edisi Ketiga. Yogyakarta: BPFE-UGM.

Dahlan Siamat. 2005. Manajemen lembaga keuangan. edisi keempat. BPFE Universitas Indonesia. Jakarta.

Danang Sunyoto. 2009. Analisis regresi dan uji hipotesis. Yogyakarta: Media Pressindo.

Hasibuan H. Malayu. 2007, Dasar-dasar perbankan. Jakarta: PT Bumi Aksara.

Kasmir. 2002. Dasar-dasar perbankan. Edisi 1. Jakarta: PT. Raja Grafindo Persada.

Komang Sri Arsani. 2009. "Analisis pengaruh indikator makroekonomi terhadap profitabilitas perbankan di Indonesia periode Januari 2006-Desember 2008”. Skripsi. Jakarta: Program Sarjana FEUI.

Limpaphayon dan Siraphat Polwitoon. 2004. "Bank relationship and firm performance: evidence from Thailand before the Asian financial crisis". Journal of Business Finance and Acounting.

Lukman Dendawijaya. 2001. Manajemen perbankan. Jakarta: Ghalia Indonesia.

Mandala Manurung Dan Pratama Rahardja. 2004. Uang, perbankan, dan ekonomi moneter. Jakarta: Lembaga Penerbit FEUI.

Mankiw N Gregory. 2003. Pengantar ekonomi. Jilid 2. Edisi 2. Jakarta: Erlangga.

Mudrajad Kuncoro, dan Suhardjono. 2002. Manajemen perbankan teori dan aplikasinya. BPFE, Yogyakarta.

Muhamad. 2005. Manajemen bank syariah. UUP AMPY KPN. Yogyakarta

Panayiotis P. Athanasoglou. 2005. Bank Specific, Industry Specific and Macroeconomic Determinants of Bank Profitability. No 25. http://www.bankofgreece.gr/BogEkdoseis/Paper200525.pdf, diakses 20 November 2010.

Sadono Sukirno. 2008. Makroekonomi teori pengantar. Edisi Ketiga. Jakarta: PT Raja Grafindo.

Samuelson Dan Nordhaus. 1996. Makroekonomi. Edisi Keempatbelas. Jakarta: Erlangga.

Selamet Riyadi. 2006. Banking assets and liability management. Edisi Ketiga. Jakarta: Lembaga Penerbit FEUI.

Sinta Sudarini. 2005. "Penggunaan rasio keuangan dalam memprediksi laba masa yang akan datang". Jurnal Akuntansi dan Manajemen. Vol XVI No 3. Desember 2005, pp. 195-207.

Undang-Undang Republik Indonesia Nomor 10 Tahun 1998 tentang Perubahan Undang-Undang Nomor 7 Tahun 1992 tentang Perbankan. http://www.komisiinformasi.go.id/assets/data/arsip/uu-bank-101998.pdf, diakses 15 November 2010. 
Analisis Faktor Internal ... (Aris Fadjar)

Wisnu Mawardi. 2005. " Analisis faktor-faktor yang mempengaruhi kinerja keuangan bank umum Indonesia (Studi kasus pada bank umum dengan total aset kurang dari 1 trilliun)". Jurnal Bisnis Strategi. Vol 14 No 1. 